\title{
Pengaruh Jenis Bahan Pengkaya dan Takaran Kompos Biochar terhadap Pertumbuhan dan Hasil Kacang Hijau (Vigna radiata L.) di Tanah Entisol Semi Arid
}

Timoteus $\mathrm{Abi}^{\mathrm{a}}$

${ }^{a}$ Fakultas Pertanian, Universitas Timor, Kefamenanu, TTU - NTT, Indonesia, email: timoteusabi02@gmail.com

\section{Article Info}

Article history:

Received 30 Juni 2020

Received in revised form 23 Juli 2020 Accepted 29 Juli 2020

DOI:

https://doi.org/10.32938/sc.v5i03.1065

Keywords:

Kompos biochar

Takaran

Vigna radiata $\mathrm{L}$

1. Pendahuluan

Kacang hijau (Vigna radiata L.) merupakan salah satu tanaman leguminoceae yang cukup penting di Indonesia. Namun perhatian masyarakat terhadap tanaman kacang hijau masih kurang. Walaupun demikian, tanaman kacang hijau memiliki beberapa kelebihan dibandingkan dengan tanaman kacang- kacangan yang lain yaitu : (a) lebih tahan terhadap kekeringan; menurut Kasno (2007), kebutuhan air untuk pertumbuhan kacang hijau sebesar 700 sampai $900 \mathrm{~mm}$ per tahun ; (b) hama dan penyakit relatif sedikit; (c) panen relatif cepat pada umur 54-54 hari; (d) cara tanam dan pengelolaan di lapangan serta perlakuan pasca panen relatif mudah; (e) kegagalan panen total relatif kecil; (f) harga jual tinggi dan stabil; serta (g) dapat dikonsumsi langsung dengan pengolahan relatif mudah (Sumarno, 1992). Kacang hijau dapat tumbuh pada semua jenis tanah asalkan kelembaban dan unsur hara cukup tersedia. Kacang hijau mempunyai potensi yang tinggi untuk dikembangkan jika dibandingkan dengan tanaman kacang-kacang lainnya, karena kacang hijau memiliki kelebihan jika ditinjau dari segi ekonomi seperti lebih tahan terhadap kekeringan, lebih sedikit terserang hama dan penyakit, dapat dipanen pada umur 55-60 hari, dapat ditanam pada tanah yang kurang kesuburannya, sertacara budidayanya lebih mudah (Sunantara,2000). Kacang hijau juga termasuk bahan pangan penting karena nutrisi yang terkandung di dalam bijinya dapat mensubtitusi fungsi daging (Duke, 1991). Kandungan gizi pada kacang hijau memiliki protein $27,29 \%$, lemak mencapai $0,77 \%$, karbohidrat sebesar $36,23 \%$, pati sebesar $19,03 \%$, dan memiliki gula sebesar 3,14\% Keunggulan lain yang dimiliki oleh kacang hijau varietas ini adalah rasa enak yang disebabkan oleh kandungan gula yang tinggi yakni 3,135\%. Namun demikian produksi kacang hijau di Indonesia rendah dan belum mampu memenuhi kebutuhan domestik. Menurut direktorat budidaya aneka kacang dan umbi, Ditjen Tanaman pangan (2012), produksi kacang hijau cenderung terus menurun, sehingga untuk kebutuhan kacang hijau dipenuhi dari impor dengan rata-rata sebesar kurang lebih 29.443 ton/tahun.

Kenyataan yang sama terjadi di wilayah Nusa Tenggara Timur (NTT). Data BPS NTT (2015) menunjukan bahwa produksi kacang hijau tahun 2012 sebesar 11. 478 ton menurun menjadi 10.139 ton pada tahun 2013. Oleh karena itu, perlu diupayakan peningkatan produktifitas kacang hijau dengan teknik budidaya kacang hijau, di antaranya dengan menggunakan teknologi budidaya yang cocok di lahan kering, seperti aplikasi arang sekam (biochar) dan pupuk kandang sapi. Tanah entisol merupakan lahan marjinal yang memiliki sifat fisik, kimia dan biologi tanah yang kurang subur karena memiliki tekstrur pasir struktur lepas permeabilitas cepat, daya menahan dan menyimpan air yang rendah serta hara rendah dan bahan organik rendah. Tanah entisol bertekstur kasar atau mempunyai konsistensi lepas, struktur lepas, tingkat agregasi rendah, peka terhadap erosi dan kandungan hara rendah serta bahan organik yang rendah maka perlu menambahkan jenis biochar, secara signifikan berpengaruh terhadap hampir semua parameter pertumbuhan dengan urutan terbaik adalah sekam padi, seresah kirinyu dan kayu putih.

Takaran biochar juga secara signifikan mempengaruhi pertumbuhan kacang tanah. Takaran 10 t/ha meningkatan pertumbuhan kacang tanah lebih baik dari pada 5 t/ha atau hanya diberi pupuk kandang 5 t/ha dan yang paling rendah adalah kontrol (tanpa biochar), kecuali biochar kayu putih yang cenderung efeknya menurun ketika takarannya ditingkatkan hingga $10 \mathrm{t} / \mathrm{ha}$. Efek serupa dilaporkan oleh Gao et al., (2017) bahwa pemberian biochar dapat meningkatkan tinggi, berat daun dan akar serta kandungan klorofil kacang tanah. Arang sekam merupakan media tanam yang praktis digunakan karena tidak perlu disterilisasi, hal ini disebabkan mikroba patogen telah mati selama proses pembakaran arang sekam mengandung unsur hara N 0,3\%, K $2031 \%$, dan beberapa unsur hara lainnya dengan $\mathrm{pH}$ 6,8. Selain hal tersebut, arang sekam juga memiliki kemampuan menahan air tinggi, bertekstur remah, siklus udara dan KTK tinggi, dan dapat mengabsobsi sinar matahari dengan efektif (Fahmi, 2013; Soemeinaboedhy dan Tejowulan, 2007).

Biochar atau arang sekam yang sudah diaplikasikan di dalam tanah dapat memperbaiki struktur fisik, kimia dan biologi tanah. Arang sekam mempunyai sifat yang mudah mengikat air, tidak mudah menggumpal harganya relatif murah, mempunyai porositas yang baik, ringan, steril dan bahannya mudah didapat (Prihmantoro, 2003). Menurut Berek et al., (2017), biochar adalah produk padat pirolisis yang kaya akan karbon, hasil konversi biomassa. Berbagai metode telah dicoba dalam aplikasi biochar, di antaranya dengan mengomposkan biochar bersama bahan organik lainnya sebelum diaplikasikan ke tanah, atau yang dikenal dengan kompos biochar, biochar juga mempunyai fungsi untuk mengikat karbon cukup besar. Biochar dapat dibuat dari berbagai bahan organik, seperti serbuk gergaji, sekam padi, buah kacang-kacangan, kulit-kulit kayu, sisa-sisa usaha perkayuan, serta bahan organik yang berasal dari sampah kertas, sampah kota dan kotoran hewan.

Ernsting et al., (2011), melaporkan bahwa biochar dapat bertindak sebagai kondisioner tanah untuk meningkatkan pertumbuhan tanaman menyediakan dan mempertahankan nutrisi dan layanan lain seperti memperbaiki sifat fisik dan sifat biologi tanah. Dari uraian diatas maka diperlukan percobaan penambahan aplikasi kompos biochar pada tanaman kacang hijau kultivar lokal ditanah kering. Pengomposan biochar arang sekam padi dengan kotoran ternak sapi dapat meningkatkan pertumbuhan serta mampu memperbaiki sruktur tanah karena bahan organik seperti kotoran ternak sapi sebagai salah satu alternatif untuk meningkatkan kesuburan pada tanah adalah melalui penggunaan pupuk organik yaitu pupuk kandang kotoran sapi Beberapa kelebihan pupuk kandang kotoran sapi adalah untuk memperbaiki struktur tanah dan berperan juga sebagai pengurai bahan organik oleh mikro organisme tanah (Parnata, 2010). Disamping itu pupuk ini juga mengandung unsur hara makro seperti $0,5 \mathrm{~N}, 0,25 \mathrm{P} 2 \mathrm{O} 5,0,5 \% \mathrm{~K} 2 \mathrm{O}$ dengan kadar air 0,5\%, dan juga mengandung unsur mikro esensial lainnya (Parnata, 2010). Dari uraian diatas maka penelitian ini bertujuan untuk mengetahui beberapa jenis kompos biochar dan takaran yang tepat terhadap pertumbuhan dan hasil kacang hijau di lahan kering, serta untuk mengetahui respon kacang hijau terhadap takaran aplikasi kompos biochar.

\section{Metode}

Penelitian ini dilaksanakan pada bulan Juni sampai September 2019 , bertempat di kebun percobaan Fakultas Pertanian, Universitas Timor, Kelurahan Sasi Kecamatan Kota Kefamenanu, Kabupaten Timor Tengah Utara Rancangan yang digunakan dalam penelitian ini adalah menggunakan rancangan petak beralur (Strip Plot Designe) $3 \times 3$ yang diulang 3 kali. Faktor pertama adalah kompos biochar $(\mathrm{P})$, yang terdiri dari 3 aras, yaitu biochar murni $\left(\mathrm{P}_{0}\right)$, kompos biochar kotoran ayam $\left(\mathrm{P}_{1}\right)$, dan kompos biochar kotoran sapi $\left(\mathrm{P}_{2}\right)$. Sedangkan pada faktor yang kedua takaran kompos biochar $(\mathrm{T})$ yaitu : 0 ton/ Ha $\left(\mathrm{T}_{0}\right), 5$ ton/Ha $\left(\mathrm{T}_{1}\right)$ dan 10 ton/Ha $\left(\mathrm{T}_{2}\right)$. Dengan demikian kombinasi perlakuannya sebagai berikut $\mathrm{P}_{0} \mathrm{~T}_{0}, \mathrm{P}_{0} \mathrm{~T}_{1}, \mathrm{P}_{0} \mathrm{~T}_{2}, \mathrm{P}_{1} \mathrm{~T}_{0}, \mathrm{P}_{1} \mathrm{~T}_{1}, \mathrm{P}_{1} \mathrm{~T}_{2}, \mathrm{P}_{2} \mathrm{~T}_{0}, \mathrm{P}_{2} \mathrm{~T}_{1}$, $\mathrm{P}_{2} \mathrm{~T}_{2}$, masing-masing diulang sebanyak 3 kali sehingga terdapat 27 satuan unit perlakuan. Parameter pengamatan dalam penelitian ini adalah suhu tanah, kadar lengas tanah, tinggi tanaman, jumlah daun, luas daun, berat kering berangkasan, berat biji per tanaman, jumlah polong per tanaman, berat biji per petak, berat 100 biji, indeks panen. Data hasil pengamatan kemudian dianalisis menggunakan sidik ragam (Anova) rancangan Striplot Designe faktorial. Ratarata perlakuan selanjutnya diuji lanjut dengan menggunakan Duncan Multiple Range Test (DMRT) dengan petunjuk Gomez dan Gomez (1984). Analisis data menggunakan program SAS 9.1. 
3. Hasil dan Pembahasan

\subsection{Hasil}

\section{Suhu Tanah}

Berdasarkan hasil sidik ragam (Anova) menunjukkan bahwa tidak terjadi interaksi antar perlakuan jenis bahan pengkaya kompos biochar dan takaran kompos biochar terhadap parameter pengamatan suhu tanah 0, 14, 28 dan 42 HST. Aras perlakuan jenis bahan pengkaya kompos biochar dan takaran kompos biochar menunjukkan bahwa tidak berbeda nyata antar aras perlakuan lainnya (Tabel 1).

Tabel 1. Suhu Tanah 0, 14, 28 dan $42 \operatorname{HST}\left({ }^{\circ} \mathrm{C}\right)$

\begin{tabular}{|c|c|c|c|c|c|}
\hline \multirow{2}{*}{$\begin{array}{c}\text { Waktu Pengamatan } \\
\text { (HST) }\end{array}$} & \multirow{2}{*}{$\begin{array}{c}\text { Jenis } \\
\text { Kompos } \\
\text { Biochar }\end{array}$} & \multicolumn{3}{|c|}{ Takaran Kompos Biochar } & \multirow[b]{2}{*}{ Rerata } \\
\hline & & $0 \mathrm{t} / \mathrm{ha}$ & $5 \mathrm{t} / \mathrm{ha}$ & $10 \mathrm{t} / \mathrm{ha}$ & \\
\hline \multirow{4}{*}{0} & Murni & 26,56 & 26,44 & 26,78 & $26,59 \mathrm{a}$ \\
\hline & Ayam & 25,22 & 26,89 & 26,78 & $26,30 \mathrm{a}$ \\
\hline & Sapi & 25,44 & 26,89 & 26,22 & $26,19 \mathrm{a}$ \\
\hline & Rerata & $25,74 \mathrm{a}$ & $26,74 \mathrm{a}$ & $26,59 \mathrm{a}$ & $(-)$ \\
\hline \multirow{4}{*}{14} & Murni & 28,56 & 29,00 & 29,11 & $28,89 \mathrm{a}$ \\
\hline & Ayam & 28,22 & 29,89 & 29,67 & $29,26 \mathrm{a}$ \\
\hline & Sapi & 29,22 & 29,00 & 29,67 & $29,30 \mathrm{a}$ \\
\hline & Rerata & $28,67 \mathrm{a}$ & $29,30 \mathrm{a}$ & $29,48 \mathrm{a}$ & $(-)$ \\
\hline \multirow{4}{*}{28} & Murni & 29,78 & 28,44 & 30,00 & $29,41 \mathrm{a}$ \\
\hline & Ayam & 29,44 & 29,56 & 28,44 & $29,15 \mathrm{a}$ \\
\hline & Sapi & 29,44 & 29,44 & 28,78 & $29,22 \mathrm{a}$ \\
\hline & Rerata & $29,56 \mathrm{a}$ & $29,15 \mathrm{a}$ & $29,07 \mathrm{a}$ & $(-)$ \\
\hline \multirow{4}{*}{42} & Murni & 29,22 & 27,89 & 29,33 & $28,81 \mathrm{a}$ \\
\hline & Ayam & 28,67 & 29,44 & 28,89 & $29,00 \mathrm{a}$ \\
\hline & Sapi & 27,78 & 27,67 & 29,33 & $28,26 \mathrm{a}$ \\
\hline & Rerata & $28,56 \mathrm{a}$ & $28,33 \mathrm{a}$ & $29,19 \mathrm{a}$ & $(-)$ \\
\hline
\end{tabular}

Keterangan: Angka pada baris dan kolom diikuti huruf sama menunjukkan tidak berbeda pada tingkat nyata a 0.05 menurut uji DMRT. (-) tidak terjadi interaksi antar faktor.

\section{Tinggi Tanaman}

Tinggi tanaman terus bertambah tinggi seiring waktu penelitian. Hasil sidik ragam (anova) menunjukkan bahwa tidak terjadi interaksi antar perlakuan jenis bahan pengkaya kompos biochar dan takaran kompos biochar terhadap pengamatan tinggi tanaman 14, 28 dan 42 hari setelah tanam. Hasil uji lanjut DMRT menunjukkan bahwa jenis bahan kompos biochar tidak berbeda nyata antar aras perlakuan pada seluruh waktu pengamatan, sedangkan takaran kompos biochar berbeda nyata, dengan aras perlakuan takaran kompos biochar 10 t/ha menunjukan tinggi tanaman tertinggi (Tabel 2).

Tabel 2. Tinggi Tanaman 14, 28 dan 42 HST (cm)

\begin{tabular}{|c|c|c|c|c|c|}
\hline \multirow{2}{*}{$\begin{array}{l}\text { Waktu Pengamatan } \\
\text { (HST) }\end{array}$} & \multirow{2}{*}{$\begin{array}{c}\text { Jenis } \\
\text { Kompos } \\
\text { Biochar }\end{array}$} & \multicolumn{3}{|c|}{ Takaran Kompos Biochar } & \multirow[b]{2}{*}{ Rerata } \\
\hline & & $0 \mathrm{t} / \mathrm{ha}$ & $5 \mathrm{t} / \mathrm{ha}$ & $10 \mathrm{t} / \mathrm{ha}$ & \\
\hline \multirow{4}{*}{14} & Murni & 5,44 & 6,90 & 8,08 & $6,81 \mathrm{a}$ \\
\hline & Ayam & 6,24 & 6,63 & 8,40 & $7,09 \mathrm{a}$ \\
\hline & Sapi & 6,34 & 6,57 & 7,56 & $6,82 \mathrm{a}$ \\
\hline & Rerata & $6,01 \mathrm{~b}$ & $6,70 \mathrm{a}$ & $8,01 \mathrm{a}$ & $(-)$ \\
\hline \multirow{4}{*}{28} & Murni & 8,00 & 12,78 & 13,56 & $11,44 \mathrm{a}$ \\
\hline & Ayam & 9,86 & 11,78 & 14,22 & $11,95 \mathrm{a}$ \\
\hline & Sapi & 8,89 & 11,44 & 13,22 & $11,19 \mathrm{a}$ \\
\hline & Rerata & $8,91 \mathrm{~b}$ & $12,00 \mathrm{a}$ & $13,67 \mathrm{a}$ & $(-)$ \\
\hline \multirow{4}{*}{42} & Murni & 11,11 & 22,00 & 21,00 & $18,04 \mathrm{a}$ \\
\hline & Ayam & 13,61 & 21,44 & 22,11 & $19,06 \mathrm{a}$ \\
\hline & Sapi & 14,78 & 19,72 & 18,89 & $17,80 \mathrm{a}$ \\
\hline & Rerata & $13,17 \mathrm{~b}$ & $21,06 \mathrm{a}$ & $20,67 \mathrm{a}$ & $(-)$ \\
\hline
\end{tabular}

Keterangan: Angka pada baris dan kolom diikuti huruf sama menunjukkan tidak berbeda pada tingkat nyata a 0.05 menurut uji DMRT. (-) tidak terjadi interaksi antar faktor.

\section{Jumlah Daun}

Jumlah daun terus bertambah banyak seiring waktu penelitian. Hasil sidik ragam (anova) menunjukkan bahwa tidak terjadi interaksi antar perlakuan jenis bahan pengkaya kompos biochar dan takaran kompos biochar terhadap pengamatan jumlah daun 14, 28 dan 42 hari setelah tanam. Hasil uji lanjut DMRT menunjukkan bahwa perlakuan jenis kompos biochar tidak berbedanyata antar aras perlakuan sedangkan aras perlakuan takaran kompos biochar berbeda nyata dari awal pengamatan hingga akhir pengamatan dengan aras perlakuan takaran kompos biochar $10 \mathrm{t} / \mathrm{ha}$ menunjukan jumlah daun tanaman terbanyak pada pengamatan 14 dan 28 HST sedangkan pada pengamatan 42 HST jumlah daun terbanyak ditunjukkan pada perlakuan kompos biochar 5 ton/ha. (Tabel 3.)

\section{Berat Kering Berangkasan}

Hasil sidik ragam (anova) menunjukkan bahwa tidak terjadi interaks antar perlakuan jenis bahan pengkaya kompos biochar dan takaran kompos biochar terhadap pengamatan berat kering berangkasan. Hasil uji lanjut DMRT menunjukkan bahwa aras perlakuan jenis bahan pengkaya kompos biochar dan takaran kompos biochar menunjukkan bahwa tidak berbedanyata (Tabel 4.).

Tabel 3. Jumlah Daun 14, 28 dan 42 HST

\begin{tabular}{|c|c|c|c|c|c|}
\hline \multirow{2}{*}{$\begin{array}{c}\text { Waktu } \\
\text { Pengamatan } \\
\text { (HST) }\end{array}$} & \multirow{2}{*}{$\begin{array}{c}\text { Jenis } \\
\text { Kompos } \\
\text { Biochar } \\
\end{array}$} & \multicolumn{3}{|c|}{ Takaran Kompos Biochar } & \multirow{2}{*}{ Rerata } \\
\hline & & $0 \mathrm{t} / \mathrm{ha}$ & $5 \mathrm{t} / \mathrm{ha}$ & $10 \mathrm{t} / \mathrm{ha}$ & \\
\hline \multirow{4}{*}{14} & Murni & 2,00 & 3,67 & 4,33 & $3,33 \mathrm{a}$ \\
\hline & Ayam & 2,00 & 4,00 & 4,67 & $3,56 \mathrm{a}$ \\
\hline & Sapi & 3,00 & 4,00 & 5,00 & $4,00 \mathrm{a}$ \\
\hline & Rerata & $2,33 \mathrm{~b}$ & $3,89 \mathrm{a}$ & $4,67 \mathrm{a}$ & $(-)$ \\
\hline \multirow{4}{*}{28} & Murni & 8,33 & 12,33 & 13,22 & $11,30 \mathrm{a}$ \\
\hline & Ayam & 9,67 & 12,78 & 12,22 & $11,56 \mathrm{a}$ \\
\hline & Sapi & 9,33 & 11,00 & 13,67 & $11,33 \mathrm{a}$ \\
\hline & Rerata & $9,11 \mathrm{~b}$ & $12,04 \mathrm{a}$ & $13,04 \mathrm{a}$ & $(-)$ \\
\hline \multirow{4}{*}{42} & Murni & 11,67 & 20,00 & 18,78 & $\overline{16,81 \mathrm{a}}$ \\
\hline & Ayam & 15,33 & 20,33 & 20,56 & $18,74 \mathrm{a}$ \\
\hline & Sapi & 16,00 & 19,33 & 19,44 & $18,26 \mathrm{a}$ \\
\hline & Rerata & $14,33 \mathrm{~b}$ & $19,89 \mathrm{a}$ & $19,59 \mathrm{a}$ & $(-)$ \\
\hline
\end{tabular}

Keterangan: Angka pada baris dan kolom diikuti huruf sama menunjukkan tidak berbeda pada tingkat nyata a 0.05 menurut uji DMRT. (-) tidak terjadi interaksi antar faktor.

Tabel 4. Berat Kering berangkasan (g)

\begin{tabular}{lllll}
\hline \multirow{2}{*}{ Jenis Kompos Biochar } & \multicolumn{3}{l}{ Takaran Kompos Biochar } & \multirow{2}{*}{ Rerata } \\
\cline { 2 - 4 } & $0 \mathrm{t} / \mathrm{ha}$ & $5 \mathrm{t} / \mathrm{ha}$ & $10 \mathrm{t} / \mathrm{ha}$ & \\
\hline Murni & 3,20 & 11,33 & 3,57 & $6,03 \mathrm{a}$ \\
Ayam & 5,57 & 12,97 & 6,53 & $8,36 \mathrm{a}$ \\
Sapi & 6,00 & 6,10 & 6,30 & $6,13 \mathrm{a}$ \\
\hline Rerata & $4,92 \mathrm{a}$ & $10,13 \mathrm{a}$ & $5,47 \mathrm{a}$ & $(-)$ \\
\hline
\end{tabular}

Keterangan: Angka pada baris dan kolom diikuti huruf sama menunjukkan tidak berbeda pada tingkat nyata a 0.05 menurut uji DMRT. (-) tidak terjadi interaksi antar faktor.

\section{Jumlah Polong per Tanaman}

Hasil sidik ragam (anova) menunjukkan bahwa tidak terjadi interaksi antar perlakuan jenis bahan pengkaya kompos biochar dan takaran kompos biochar terhadap pengamatan jumlah polong per tanaman. Hasil uji lanjut DMRT menunjukkan bahwa aras perlakuan jenis kompos tidak berbedanyata sedangkan aras perlakuan takaran kompos berbeda nyata dengan aras perlakuan takaran kompos biochar 10 t/ha menunjukan jumlah polong per tanaman terbanyak (Tabel 5.).

Tabel 5. Jumlah Polong per Tanaman

\begin{tabular}{ccccc}
\hline \multirow{2}{*}{ Jenis Kompos Biochar } & \multicolumn{2}{c}{ Takaran Kompos Biochar } & \multirow{2}{*}{ Rerata } \\
\cline { 2 - 4 } & $0 \mathrm{t} / \mathrm{ha}$ & $5 \mathrm{t} / \mathrm{ha}$ & $10 \mathrm{t} / \mathrm{ha}$ & \\
\hline Murni & 4,89 & 9,22 & 15,89 & $10,00 \mathrm{a}$ \\
Ayam & 5,78 & 12,11 & 8,67 & $8,85 \mathrm{a}$ \\
Sapi & 6,00 & 12,00 & 12,11 & $10,04 \mathrm{a}$ \\
\hline Rerata & $5,56 \mathrm{~b}$ & $11,11 \mathrm{a}$ & $12,22 \mathrm{a}$ & $(-)$ \\
\hline
\end{tabular}

Keterangan: Angka pada baris dan kolom diikuti huruf sama menunjukkan tidak berbeda pada tingkat nyata $\alpha 0.05$ menurut uji DMRT. (-) tidak terjadi interaksi antar faktor.

\section{Berat Biji Per Tanaman}

Hasil sidik ragam (anova) menunjukkan bahwa tidak terjadi interaksi antar perlakuan jenis bahan pengkaya kompos biochar dan takaran kompos biochar terhadap pengamatan berat biji per tanaman. Hasil uji lanjut DMRT menunjukkan bahwa aras perlakuan jenis bahan pengkaya kompos biochar tidak berbedanyata sedangkan aras perlakuan takaran kompos biochar menunjukkan berbeda nyata dengan aras perlakuan takaran 10 t/ha menghasilkan berat biji pertanaman tertinggi (Tabel 6.).

\section{Tabel 6. Berat Biji per Tanaman}

\begin{tabular}{|c|c|c|c|c|}
\hline \multirow{2}{*}{ Jenis Kompos Biochar } & \multicolumn{3}{|c|}{ Takaran Kompos Biochar } & \multirow{2}{*}{ Rerata } \\
\hline & $0 \mathrm{t} / \mathrm{ha}$ & $5 \mathrm{t} / \mathrm{ha}$ & $10 \mathrm{t} / \mathrm{ha}$ & \\
\hline Murni & 4,76 & 7,53 & 14,11 & 8,80 a \\
\hline Ayam & 5,67 & 10,01 & 8,89 & 8,19 a \\
\hline Sapi & 7,27 & 11,03 & 12,89 & $10,40 \mathrm{a}$ \\
\hline Rerata & $5,90 \mathrm{~b}$ & $9,53 \mathrm{a}$ & $11,96 \mathrm{a}$ & $(-)$ \\
\hline
\end{tabular}

Keterangan: Angka pada baris dan kolom diikuti huruf sama menunjukkan tidak berbeda pada tingkat nyata a 0.05 menurut uji DMRT. (-) tidak terjadi interaksi antar faktor.

\section{Berat Biji Per Petak}

Hasil sidik ragam (anova) menunjukkan bahwa tidak terjadi interaksi antar perlakuan jenis bahan pengkaya kompos biochar dan takaran kompos biochar terhadap pengamatan berat biji per petak. Hasilujilanjut DMRT menunjukkanbahwaarasperlakuanjeniskomposbiocharmenunjukkantidakberbed anyatasedangkanarasperlakuantakaran kompos biochar berbeda nyata, dengan takaran kompos biochar $10 \mathrm{t} / \mathrm{ha}$ menghasilkanberat biji per petak terberat (Tabel 7). 
Tabel 7. Berat Biji per Petak (g)

\begin{tabular}{ccccc}
\hline \multirow{2}{*}{ Jenis Kompos Biochar } & \multicolumn{3}{c}{ Takaran Kompos Biochar } & \multirow{2}{*}{ Rerata } \\
\cline { 2 - 4 } & $0 \mathrm{t} / \mathrm{ha}$ & $5 \mathrm{t} / \mathrm{ha}$ & $10 \mathrm{t} / \mathrm{ha}$ & \\
\hline Murni & 31,43 & 52,03 & 76,90 & $53,46 \mathrm{a}$ \\
Ayam & 36,40 & 66,83 & 56,90 & $53,38 \mathrm{a}$ \\
Sapi & 43,73 & 57,57 & 65,00 & $55,43 \mathrm{a}$ \\
\hline Rerata & $37,19 \mathrm{~b}$ & $58,81 \mathrm{ab}$ & $66,27 \mathrm{a}$ & $(-)$ \\
\hline
\end{tabular}

Keterangan: Angka pada baris dan kolom diikuti huruf sama menunjukkan tidak berbeda pada tingkat nyata $\alpha 0.05$ menurut uji DMRT. (-) tidak terjadi interaksi antar faktor.

\section{Indeks Panen}

Hasil sidik ragam (anova) menunjukkan bahwa tidak terjadi interaksi antar perlakuan jenis bahan pengkaya kompos biochar dan takaran kompos biochar terhadap nilai indeks panen. Hasil uji lanjut DMRT menunjukkan bahwa aras perlakuan jenis bahan pengkaya kompos biochar maupun takaran kompos biochar menunjukkan tidak berbedanyata antar aras perlakuan (Tabel 8).

Tabel 8. Indeks Panen (\%)

\begin{tabular}{ccccc}
\hline \multirow{2}{*}{ Jenis Kompos Biochar } & \multicolumn{3}{c}{ Takaran Kompos Biochar } & \multirow{2}{*}{ Rerata } \\
\cline { 2 - 4 } & 0 t/ha & 5 t/ha & 10 t/ha & \\
\hline Murni & 90,70 & 82,70 & 94,54 & 89,31 a \\
Ayam & 87,02 & 80,07 & 89,90 & $85,66 \mathrm{a}$ \\
Sapi & 87,28 & 89,33 & 91,11 & $89,24 \mathrm{a}$ \\
\hline Rerata & $88,33 \mathrm{a}$ & $84,03 \mathrm{a}$ & $91,85 \mathrm{a}$ & $(-)$ \\
\hline
\end{tabular}

Keterangan: Angka pada baris dan kolom diikuti huruf sama menunjukkan tidak berbeda pada tingkat nyata $\alpha 0.05$ menurut uji DMRT. (-) tidak terjadi interaksi antar faktor.

\subsection{Pembahasan}

Berdasarkan hasil pengamatan pada lapangan dapat menunjukan bahwa pemberianjenis bahan pengkaya kompos biochar dan takaran kompos biochar tidak menunjukan bahwa tidak terjadi interaksi pada semua variabel yang diamati. Hasil penelitian menunjukan bahwa pemberian jenis bahan pengkaya kompos biochar kotoran sapi dan takaran kompos biochar 10 t/ha yang diamati berpengaruh positif terhadap suhu tanah. Suhu tanah yang tidak terlalu tinggi menunjukkan bahwa keadaan tanah cukup dalam mengikat air. Saleh et al., (2012) mengungkapkan bahwa biochar yang tinggi dapat meningkatkan kemampuan tanah dalam mengikat air sehingga lebih tersedia bagi tanaman dan mahkluk hidup lainnya. Hal ini sependapat dengan Dariah dan Sutono, (2013) bahwa pengaruh positif terhadap peningkatan pori tanah berdampak terhadap kemampuan jenis bahan pengkaya kompos biochar dalam mengikat air yang bermanfaat dalam meningkatkan efisiensi penggunaan air ke dalam tanah. Dampak dari faktor lingkungan tersebut akan berpengaruh terhadap pertumbuhan dan hasil tanaman.

Hasil penelitian menunjukan bahwa pemberian jenis bahan pengkaya kompos biochar kotoran sapi dan takaran kompos biochar 10 t/ha yang diamati berpengaruh positif terhadap pertumbuhan dan hasil tanaman kacang hijau yang dapat diekspresikan dalam bentuk (tinggi tanaman tertinggi, jumlah daun 14 HST tertinggi, luas daun terluas, panjang akar terpanjang, jumlah bintil akar terbanyak, bintil akar efektif terbanyak, jumlah polong per tanaman terbanyak, panjang polong per tanaman terpanjang, berat biji per tanaman terberat, berat biji perpetak terberat berat 100 biji terberat dan nilai indeks panen tertinggi). Hal ini dikarenakan kombinasi jenis bahan pengkaya kompos biochar kotoran sapi dan takaran kompos biochar 10 t/ha telah mampu menyediakan unsur hara yang cukup untuk pertumbuhan dan hasil tanaman kacang hijau. Hasil penelitian Nugroho (2013) menyatakan bahan organik berfungsi sebagai sumber bahan energi bagi mikroba dan merupakan salah satu komponen tanah yang sangat penting bagi ekosistem tanah, dimana bahan organik merupakan sumber pengikat hara dan sebagai substrat bagi mikroba tanah. Hanafiah (2010) juga menyatakan bahwa penambahan bahan organik dapat meningkatkan KTK dan $\mathrm{pH}$ tanah yang berpengaruh terhadap penyerapan hara. Kombinasi pemberian jenis bahan pengkaya kompos biochar kotoran sapi dan takaran kompos biochar 10 t/ha dapat menciptakan medium yang baik bagi pertumbuhan tanaman kacang hijau dimana selain menyediakan ketersediaan hara kombinasi keduanya juga dapat meningkatkan kualitas tanah menjadi lebih baik. Unsur hara dapat terserap dengan baik akibat perbaikan sifat-sifat tanah, sehingga akar dapat menyerap dan mentranslokasikan unsur hara ke seluruh organ tanaman khususnya untuk pertumbuhan tanaman. Hal ini sesuai dengan pernyataan Hakim et al., (1989), bahwa ketersediaan unsur hara tanaman tidak terlepas dari kondisi tanah. Kondisi tanah yang baik akan mendukung pertumbuhan awal tanaman. Menurut Harjadi (1991) tanaman akan tumbuh dengan baik apabila unsur hara yang dibutuhkan cukup tersedia dalam bentuk yang dapat diserap oleh tanaman. Atmojo (2007), mengemukakan bahwa penambahan bahan organik akan meningkatkan kemampuan menahan air, sehingga mampu menyediakan air dalam tanah untuk pertumbuhan tanaman. Peran air sebagai pelarut unsur hara di dalam tanah, menyebabkan tanaman dapat dengan mudah mengambil hara tersebut sebagai bahan makanan melalui akar dan sekaligus mengangkut hara tersebut kebagian-bagian tanaman. Sarief (1986) juga menyatakan dengan pemberian bahan organik kedalam tanah dapat peningkatkan berat basah dan berat kering dan secara otomatis akan meningkatkan rasio tajuk dan akar pada akhirnya dapat meningkatkan pertumbuhan dan hasil tanaman.

\section{Simpulan}

Hasil penelitian menunjukkan bahwa tidak terjadi interaksi pada semua variabel yang diamati pada tanaman kacang hijau (Vigna Radiata L.), aras perlakuan jenis bahan pengkaya tidak berbedanyata pada semua parameter pengamatan sedangkan aras perlakuan takaran kompos biochar 5 t/ha maupun $10 \mathrm{t} / \mathrm{ha}$ tidak berbedanyata pada keseluruhan parameter pengamatan.

\section{Pustaka}

Atmojo Suntoro Wongso, 2007. Peranan Bahan Organik Terhadap Kesuburan Tanah dan Upaya Pengelolannya.

Berek, A.K., Tabati, P.O., Keraf, U.U., Bere, E., Taekab, R. \& Wora, A. 2017. Perbaikan Pertumbuhan Dan Hasil Kacang Tanah Di Tanah Entisol Semiarid Melalui Aplikasi Biochar. Savana cendana, 2(03):56-58.

BPS NTT. 2015. Berita Resmi Statistik. BPS Provinsi Nusa Tenggara Timur. No.08/03/53/Th.XVIII, 2 Maret 2015.

Dariah A., Sutono N. L. 2013. The Effect Of Biochar On Soil Quality And Maize Productivity In Upland In Dry Climate Region. 11 th International Conference the East and South East Asia Federation of Soil Science Societies. 21-24 October. Bogor. Indonesia.

Direktorat Budidaya Aneka kacang dan Umbi, Ditjen Tanaman Pangan. 2012. Pedoman Teknis Pengelolaan Produksi Kacang Tanah, Kacang Hijau dan aneka kacang.

Duke, J.A, 1991. Legumens Of World Economic Importance. Plenum Pres, New York And London. Hal : 294

Ernsting Almuth Rachel Smolker, Helena Paul. 2011. Biochar and Carbon Markets, Biofuels, Volume 2, Issue 1

Fahmi, I. Z. 2013. Media Tanam Hidroponik Dari Arang Sekam. Balai Besar Perbenihan dan Proteksi Tanaman Perkebunan. Surabaya.

Gao, M., Liu, X., Li, N., Luo, P., Han, X., Yang, J. 2017. The Impact $O f$ Application Of Biocar On Peanuts Growing. IOP Conf. Ser.: Mater. Sci. Eng. 274012156.

Gomez, K.A. \& Gomez, A.A. 1984. Statistical Procedures for Agricultural Research. New York: John Wiley \& Sons

Hanafiah, K.A. 2010. Dasar-dasar Ilmu Tanah. PT. Raja Grafindo Persada. Jakarta.

Hakim, N., M. Y. Nyakpa, A. M. Lubis, S.G. Nugroho, M. R. Saul, M. A. Diki, G. B. Hong, H. Bailey. 1986. Dasar-Dasar Ilmu Tanah. Universitas Lampung. Bandar Lampung.

HarjadiS.M.M.S. 1991. Pengantar Agronomi, Gramedia, Jakarta.

Kasno, A. 2007. Kacang Hijau, alternatif yang menguntungkan ditanam di lahan kering.

Sumarno. 1992. Arti Ekonomis dan kegunaan kacang hijau. Dalam T. Adisarwanto, Sunardi, A. Winarto, dan sugiyono (Ed ). Kacang Hija. Monograf No. 9. Balai penelitian tanaman pangan. 11 hal.

Nugroho, Y.A. Sugito Y. Agustina L. 2013. Kajian Penambahan Beberapa Dosis Pupuk Hijau Dan Pengaruhnya Terhadap Pertumbuhan Tanaman Selada (Lactuca sativa L). J.Exp. Life Sci. Vol. 3 No. 2, 2013.

Prihmantoro, H. 2003. Memupuk Tanaman Sayur. Penebar Swadaya. Jakarta.

Parnata, A. 2010. Meningkatkan Hasil Panen dengan Pupuk Organik. PT. Agromedia Pustaka. Jakarta.

Sarief, S. 1986. Kesuburan dan Pemupukan Tanah Pertanian. Pustaka Buana. Bandung.

Sunantara, I.M.M. 2000. Teknik produksi benih kacang hijau. No. Agdex: 14/35. No. Seri: 03/ Tanaman/ 2000/September 2000. Instalasi Penelitian Dan Pengkajian Teknologi Pertanian Denpasar Bali.

Soemeinaboedhy, N. dan R. S. Tejowulan. 2007. Pemanfaatan Beberapa Macam Arang Sebagai Sumber Unsur Hara P dan K Serta Sebagai Pembenah Tanah. Jurusan Ilmu Tanah Fakultas Pertanian Universitas Mataram. Agroteksos. 17(2): 114-122.

Saleh Maher E. , Amal H. Mahmoud and Mohamed Rashad, 2012. Peanut Biochar As A Stable Adsorbent For Removing N [H.Sub.4]-N From Wastewater: A Preliminary Study. Advances in Environmental Biology, p. 2170+. Gale Academic OneFile 